\title{
PREVALENCE OF NON-COMPLETION AMONG POSTGRADUATE STUDENTS IN SELECTED PUBLIC UNIVERSITIES IN KENYA
}

\author{
Sophia Mwende Mugendi, \\ Eunice Njango Githae \\ Kenyatta University, \\ School of Humanities \& Social Sciences, \\ Department of Psychology, \\ PO Box 43844 - 00100 Nairobi, \\ Kenya
}

\begin{abstract}
:
Non-completion among university students is a common phenomenon in many parts of the world. Many causes of this problem have been advanced and among them are institutional and individual reasons like financial ability, gender and motivation to complete studies. Psychological distress though not investigated thoroughly has been cited as one of the problems leading to non-completion. The study sought to establish the prevalence of non-completion among postgraduate students in selected public universities in Kenya. Weiner Attribution theory (1985) informed the study. The study adopted a correlation research design, and it was conducted in two selected public universities in Uasin Gishu and Nairobi counties targeting a population of 945 postgraduate students. A sample of $(\mathrm{N}=273)$ was obtained from the two selected public universities through systematic random sampling. The study used questionnaires, focus group discussions and document analysis in collecting data. Reliability of the questionnaire was established using Split half method from a pilot study conducted in Uasin Gishu County. Statistical package for the social sciences SPSS 23 was also used to analyse the data. Descriptive statistics to analyze demographic data while Pearson correlation was employed to test the relationship between psychological distress and non-completion. Regression analysis was used to clarify the nature of relationship with the variable. Findings indicated an average non-completion rate of 2.5 years with most students citing financial constraints as the primary cause of their non-completion. The study recommended that students who wished to further their studies should first establish a financial channel or safe for the education journey before they registered for their studies. This would ensure that they would avoid dropping out of school due to a lack of school fees. The study further recommended that students should choose a study model that would favour their schedules to ensure that they did not go through a lot of stress trying to accomplish several tasks simultaneously.
\end{abstract}

${ }^{i}$ Correspondence: email mwendesophia123@gmail.com 
Keywords: non-completion, postgraduate students, public universities

\section{Introduction}

Non-completion of studies is being encountered globally today at a very high rate. Researchers worldwide have provided contradicting reasons for prevalence of noncompletion among students. For instance, In US, researchers have suggested a noncompletion rate of $60 \%$ and revealed gaps in the higher education system that should serve to meet student's needs. More so, the needs to work and go to school at the same time (Gates Foundation, 2009). According to a study conducted in US reported a high prevalence of non-completion among students. It found out that up to $50 \%$ of their students did not complete their studies (Barefoot, 2014). A Canadian study by Lindsay (2013), reported non-completion in graduate programs to have been a point of societal, institutional and individual level concerns. Upon entry to graduate school demographic and background, characteristics such as being married and having children were associated with a reduced likelihood of completing school. A student was more effective when they could balance their social, psychological and scholarly education (Anderson, Guan \& Koc, 2016).

A study by in New Zealand by McKenzie (2005), study on non-completion suggested that their students also experienced non-completion and a range of between $20-30 \%$ of the students enrolled in a developmental education program did not complete their study. This study agreed with Ugolini (2002), study that found out that factor like low social economic status had an impact on non-completion. A Canadian study at York University studied a cohort of 1993-1995 on non-completion and if their race impacted on degree success. Grayson (1998) suggested that $24 \%$ of the cohort studied did not complete their degree and that a lower difference of non-completion existed between students of Black, South Asian, Chinese and European Origin.

In Africa similar claims of non-completion have been reported by different researchers and they have too attributed non-completion to a number of factors such as finances, personal reasons, institution factors and examination repeats. For instance, In South Africa, Herman (2011), attributed a 50\% of non-completion to personal reasons, student lack of ability and motivation to do a postgraduate program. A study by Mukami and Wang'eri (2016), did a study on attrition in private universities in Nairobi and established a $37 \%$ non-completion rate. The study further reported that more male students knew the whereabouts of other male students who had not completed their studies unlike the female students (ibid). According to Rong'uno (2016), on students' related factors influencing completion rates of doctoral students, a 50\% non-completion of cohort 2001-2008 enrolment was established.

In Kenya, Barasa and Omulando (2018), reported that an estimate of only $11 \%$ of doctoral students graduates averagely in 6 years. Additionally, student's background characteristics like age, gender, nationality, and financial aid are some identifies factors influencing success. Mukami (2016), did a postgraduate study on attrition in private 
universities in Nairobi and established a 37\% non-completion rate. The author also reported that more male students had not completed their studies compared to their female counterparts. Another study conducted in Kenya by Rong'uno (2016), on students' related factors influencing completion rates of doctoral students. It highlighted a 50\% non-completion of cohort 2001-2008 enrolment. Mwebi \& Simatwa (2013), on private universities in Kenya did a similar study, reported that a cohort of the 2007/2008 academic year discovered up to $1.7 \%$ drop out rate and $3.2 \%$ attrition rate. All these studies indicate the extent of the non-completion problem. While reasons for noncompletion have been cited as financial ability, age of the student, institutional factors and lack of motivation to complete courses enrolled for, only few of these have assessed the role of psychological distress as a predicting factor in attrition. It is in this light that the study sought to determine the prevalence of non-completion among postgraduate students in selected public universities in Kenya.

\section{Research Objective}

To determine the prevalence of non-completion among postgraduate students in selected public universities in Kenya.

\section{Research Hypothesis}

What is the prevalence of non-completion among postgraduate students in selected public universities in Kenya?

\section{Literature Review}

\subsection{Demographic factors associated with Non-completion}

Demographic factors like gender, discipline, marital status and finances has been attributed to non-completion among postgraduate students. For instance, in USA, noncompletion rate is more than $50 \%$ across disciplines and that more women drop out as compared to men. Again, students drop out of humanities and social sciences at a higher rate compared to those in pure sciences (Council of graduate schools 2008; Golde 2005; Nettles \& Millet, 2006). A study done in Ontario, Canada by Rhea, Kevin and Derek (2013), on student attrition in midwifery education program used an online survey questionnaire among senior level students, year three and four in two universities. They found out that student who withdrew from school were those who felt academically not supported and students taking a leave for example maternity (ibid). The study is unique as it brings out the academic support as an aspect leading to non-completion.

Studies done in Canada on social demographic characteristics have shown significance to non-completion more so with the undergraduate population in particular male, married parent students are more likely to drop out from school in comparison with their counterparts. (Lambert, Zeman, Allen, \& Bussiere, 2004; Shaienks \& 
Gluszynski, 2007). Concurring findings are seen from both Canadian and American noncompletion trends. First generation students and students from low social economic backgrounds have a higher likelihood of dropping out (Bowen, Chingos, \& Mcphagon, 2009, Ishitani, 2006; Lambert et al., 2004).

In Africa, a South African study done among graduate program leaders who were of the opinion that attrition happened due to students' personal reasons, students' lack of ability, skills or motivation to do a graduate program, students' lack of financial support, poor supervision and an inflexible policy of the universities (Mouton, 2011). According to a research conducted by Yusuf, Felicia and Aina (2018), on "demographic factors as correlates of doctoral degree completion in Nigerian library schools". It indicated a relationship between demographic factors and time-to-completion. It takes an average of 5.7 years to complete a doctoral degree in Nigeria library schools irrespective of mode of study. This study tends to lean on the doctoral students missing out than the master's students (ibid). This research agrees with the global studies that there is a relationship between demographic factors and non-completion.

A Local study in Kenya by Mukami and Wang'eri (2016), analyzed demographic data and examination retakes, semester deferments and student drop outs. She reported that more male students knew about other male students who had dropped out as compared to the female students. Another Kenyan study by Kyalo and Chumba (2011), among Egerton University students found that in order to determine whether a student is able to complete a degree program, a student's interpersonal skills, the university environment and the social economic status of the family needs to be looked at. This study agrees with Mukami (2016) and Rong'uno (2016), on the university environment and social economic status of the family

\subsection{Prevalence of Non-completion}

Non-completion of studies by postgraduate students in institutions of higher learning continues to be high and persistent. This is depicted in Table 1 below.

Table 1: Global, regional and local non-completion rates

\begin{tabular}{|c|c|c|c|c|}
\hline Country & Subject & $\begin{array}{c}\text { Definition of } \\
\text { Non-completion }\end{array}$ & $\begin{array}{c}\text { Non-completion } \\
\text { rate }(\%)\end{array}$ & Citation \\
\hline \multirow{2}{*}{ USA } & \multirow{2}{*}{$\begin{array}{c}\text { Multiple } \\
\text { Universities }\end{array}$} & $\begin{array}{c}\text { Completion versus } \\
\text { non-completion }\end{array}$ & 50 & 2 \\
\hline & & $\begin{array}{c}\text { Completion versus } \\
\text { non-completion }\end{array}$ & 60 & 14 \\
\hline Italy & 76 universities & Left faculty & 65 (2001 enrolment) & 57 \\
\hline UK & $\begin{array}{c}\text { Multiple Traditional } \\
\text { Universities } \\
\end{array}$ & $\begin{array}{c}\text { First-year } \\
\text { non-completion }\end{array}$ & 15.5 & 9 \\
\hline Australia & $\begin{array}{c}\text { Multiple faculties \& } \\
\text { Universities }\end{array}$ & $\begin{array}{c}\text { First-year } \\
\text { non-completion }\end{array}$ & 28.2 (2004 enrolment) & 11 \\
\hline New-Zealand & Single University & $\begin{array}{c}\text { Left without passing } \\
\text { any course }\end{array}$ & 20 to 30 & 33 \\
\hline Canada & $\begin{array}{c}\text { Multiple } \\
\text { University-wide }\end{array}$ & $\begin{array}{c}\text { Left after } 1 \text { year } \\
\text { of study }\end{array}$ & 24 (cohort 1993-1994) & 19 \\
\hline South Africa & Multiple Universities & Obstacles & 50 & 20 \\
\hline
\end{tabular}




\begin{tabular}{|l|c|c|c|c|}
\hline \hline & & to success & & \\
\hline \multirow{4}{*}{ Kenya } & $\begin{array}{c}\text { 13 Private } \\
\text { Universities }\end{array}$ & $\begin{array}{c}\text { Dropping out, } \\
\text { Semester deferment }\end{array}$ & 37 & 36 \\
\cline { 2 - 5 } & $\begin{array}{c}\text { 3 Public } \\
\text { Universities }\end{array}$ & $\begin{array}{c}\text { Completion versus } \\
\text { Non-completion }\end{array}$ & 50 (cohort 2001-2009) & 46 \\
\hline
\end{tabular}

Source: Leaving rates reported for countries outside south Africa Journal article

In the United State of America, two studies revealed a non-completion prevalence of 50\% and $60 \%$ respectively. The first study was done by Barefoot (2004), on higher education revolving door; confronting the problem of students dropping out. He reported a noncompletion prevalence of $50 \%$ among first year college students and recommended that for universities to retain students they need to focus on offering success courses to the students to help prepare them for the long journey ahead through use of classroom instructions. The second study conducted by Gate foundation (2009). Researchers surveyed 600 young adults aged between 22-30 years on why they left college. Findings revealed gaps in higher education systems more so with students who worked and attended school at the same time. These two studies imply a very high non-completion rate among undergraduate students a difference from the current study that targets noncompletion among postgraduate population.

In York University, Canada Grayson (1998), studied a cohort of 1993-1994 students establishing non-completion of students and its correlate to their race. The findings were that the non-completion rate of students was $24 \%$ and there was a lower difference of non-completion between Black, South Asians, Chinese and European students. Additionally, he cautioned that there was a slight effect of race on involuntary dropping out of college. These findings implied a weak relationship between non-completion and race. However, the study does not give the individual factors that may influence completion hence the current study aims at elucidating this relationship.

In Italy, a study involving 76 universities observed a cohort enrolled in 2007-2008 for non-completion. They found out that most students drop out before moving to the second year up to $65 \%$ and only one-third completed their study. Other interesting findings were student's background had a high impact on their inactivity in school (Ugolini, 2002). Ugolini study implied that non-completion was high and student's background had influence on attrition.

A survey done in the United Kingdom by Cutler and Pulko (2002), examined undergraduate attrition against students' backgrounds, focusing on resources, staffstudent ratio, and admission. They reported a slightly lower non-completion rate of $15.5 \%$ attributing it to financial problems, pastoral care, disability, and gender. An Australian university by Danaher, Bowger, Somasundaram (2008), studied students who joined the first term in 2004 using an intra-organization comparative approach; the noncompletion prevalence was at $28.5 \%$. The study recommended that universities that wished to reduce non-completion might adopt integration and strategies that are both faculty and program differences. These three studies agreed that student backgrounds and institutional factors correlate with non-completion and to solve the non-completion 
problem an integration of these areas required. McKennzie (2005), carried out a developmental education program study in New Zealand. It aimed at establishing noncompletion among the students in Developmental Education programs. The study found a range of $20 \%$ to $30 \%$ of non-completion among the student respondents.

In South Africa, Herman (2011), attributed 50\% of non-completion among postgraduates to personal reasons, students' lack of ability, skills, or motivation to do a postgraduate program. In Kenya, Mukami (2016), studied attrition prevalence in private universities in Nairobi. She sampled 387 current students and 60 students who had dropped out from 13 universities in Nairobi. This study illustrated $37 \%$ of attrition among undergraduate students. This study differs with current study on exclusion of public universities; undergraduate population was and its consideration of universities in the Nairobi region. Rong'uno (2016), in his study of student related factors influencing completion rates of doctoral studies in selected public universities in Kenya. He used a descriptive design and a sample of 388 doctoral students and 184 lecturers in three universities. The study highlighted that completion time between 2001-2008 enrolments was 9 years and the completion rate was up to $50 \%$ to $70 \%$. In addition, students enrolled after 2009 had a non-completion of 50\% pointing that non-completion among doctoral students was very high and students took a long time to degree. Mukami and Rong'uno studies depict the high non-completion prevalence in Kenya, having sampled private and public universities respectively.

\section{Research Methodology}

The study adopted a correlation research design and it was conducted in two selected public universities in Uasin Gishu and Nairobi counties targeting a population of 945 postgraduate students. A sample of $(\mathrm{N}=273)$ was obtained from the two selected public universities through systematic random sampling. The study used questionnaires, focus group discussions and document analysis in collecting data. Reliability of the questionnaire was established using Split half method from a pilot study conducted in Uasin Gishu County. Statistical package for the social sciences SPSS 23 was also used to analyse the data. Descriptive statistics were used to analyze demographic data while Pearson correlation was employed to test the relationship between psychological distress and non-completion. Regression analysis was used to clarify the nature of relationship with the variable. 


\section{Results and Discussion}

\subsection{Demographic Characteristics of Respondents}

\section{a. Participant's Gender}

The study collected data on respondents' gender because it was important in finding gender differences in non-completion rates. Figure 1 depicts the distribution of this demographic.

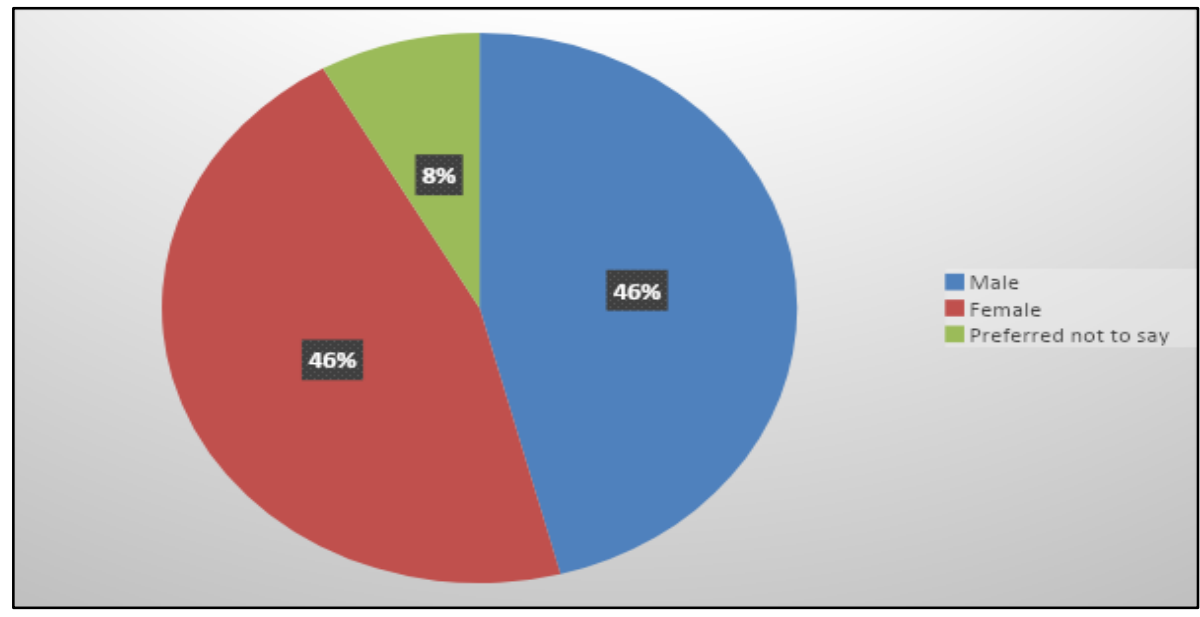

Figure 1: Participants Gender

As shown in Figure 1, 46\% of participants were males, with a further $46 \%$ being females, while $8 \%$ preferred not to say. Getting data on gender was important for this study because gender was one of the demographic characteristics that was examined in the study in association with non-completion among postgraduates. The research needed to examine this aspect because there are past scholars who have found gender to influence non-completion among postgraduate students. Rhea et al. (2013), revealed that women dropped out of school to go to maternity and parenting. Jiranek (2010), also indicated that men were more certainly to complete postgraduate studies than women, meaning according to this study, gender influenced non-completion.

\section{b. Age of Participants}

Understanding the age factor in this study was vital because age was one of the demographic characteristics compared with non-completion. Table 1 shows the age category.

Table 2: Participants Age Category

\begin{tabular}{|l|c|c|}
\hline Age category & Frequency & Percent \\
\hline 22-30 years & 59 & 25.8 \\
\hline $30-40$ years & 88 & 38.4 \\
\hline $40-50$ years & 49 & 21.4 \\
\hline 50 years and above & 33 & 14.4 \\
\hline Total & 229 & 100.0 \\
\hline
\end{tabular}


From Table 2, 38.4\% of respondents were aged between 30 to 40 years, $25.8 \%$ were aged between 22 to 30 years, while $21.4 \%$ were aged between 40 to 50 years. According to the results on age, the majority of the students were between 30 to 40 years of age followed by a group between 22 to 30 years. According to these findings, the majority of postgraduate students were in their twenties and thirties. However, there was also an indication that a considerable number of postgraduate students were in their forties. These findings agreed with the research by Mulvey and Nicholson (2014), who found out that in the USA, the average age of students taking masters in physics was 29.2 with 10\% of students being at 35 years or above. A survey by GradSchoolHub (2020), also concurred with the study findings. The survey found out that the average age for master's degree students was 33 years of age. The results could be because individuals were more vibrant between their 20 and 40 and many would want to have accomplished their education and career goals by the age of 40 .

\section{c. Respondents Marital Status}

Marital status was explored as a demographic characteristic aiming to find out whether it influenced non-completion among postgraduate students.

Table 3: Respondents Marital Status

\begin{tabular}{|l|c|c|}
\hline Marital Status & Frequency & Percent \\
\hline No response & 2 & .9 \\
\hline Married & 93 & 40.6 \\
\hline Others & 50 & 21.8 \\
\hline Single & 84 & 36.7 \\
\hline Total & 229 & 100.0 \\
\hline
\end{tabular}

As shown in table 3, 40.6\% of participants were married, $36.7 \%$ were single, while $21.8 \%$ indicated other on their marital status. Understanding marital status in this research was important. Marital status was a demographic characteristic being investigated and whether it influenced non-completion among postgraduate students. Some researchers in the past investigated the relationship between marital status and noncompletion/success among postgraduate students. Jansen \& Hofman (2020), study aimed at establishing if Ph.D. students background and program characteristics were related to their success reported no relationship between marital status and academic success. Price (2005), study on investigating the marital status and gender had an impact on completion rates discovered that married female students were not any likely to graduate but they do complete their degree. These two but studies found no significant relationship between marital status and non-completion.

\section{d. Participants Religious Affiliation}

Finding out what religious affiliation the postgraduate students belonged to was important for the study because religion was one of the demographics the researcher investigated whether they influenced non-completion among university students. Some 
students committed more time to religious activities than others did therefore the researcher needed to find out if these differences could have influenced time to complete the degree.

Table 4: Participants Religious Affiliation

\begin{tabular}{|l|c|c|}
\hline Religious Affiliation & Frequency & Percent \\
\hline Christian & 156 & 68.1 \\
\hline Indigenous Religion & 16 & 7.0 \\
\hline Muslim & 26 & 11.4 \\
\hline Others & 31 & 13.5 \\
\hline Total & 229 & 100.0 \\
\hline
\end{tabular}

From table 4 , the majority of participants (68.1\%) were Christians, $13.5 \%$ indicated other religions, while $11.4 \%$ were Muslims. Scholars in the past had investigated the relationship between religious affiliation and non-completion and had various conclusions. Some researchers found no significant relationship between religious affiliation and non-completion among students (Zubairu \& Sakariyau, 2016; Taghavinia \& Motavassel, 2015). However, some scholars revealed that religion acted as a motivation for students to take their studies seriously hence reducing non-completion (Elms, 2007; Rosliza, Inayah, Emiza, Merani, \& Yusliena, 2017).

\section{e. Mode of Academic Financing of Participants}

Financial status was majorly cited as the cause of non-completion. This study examined the relationship between psychological distress and non-completion, and hence understanding finances as an intervening variable was important because it had a big role to play in the completion of the studies.

Figure 2: Mode of Academic Financing

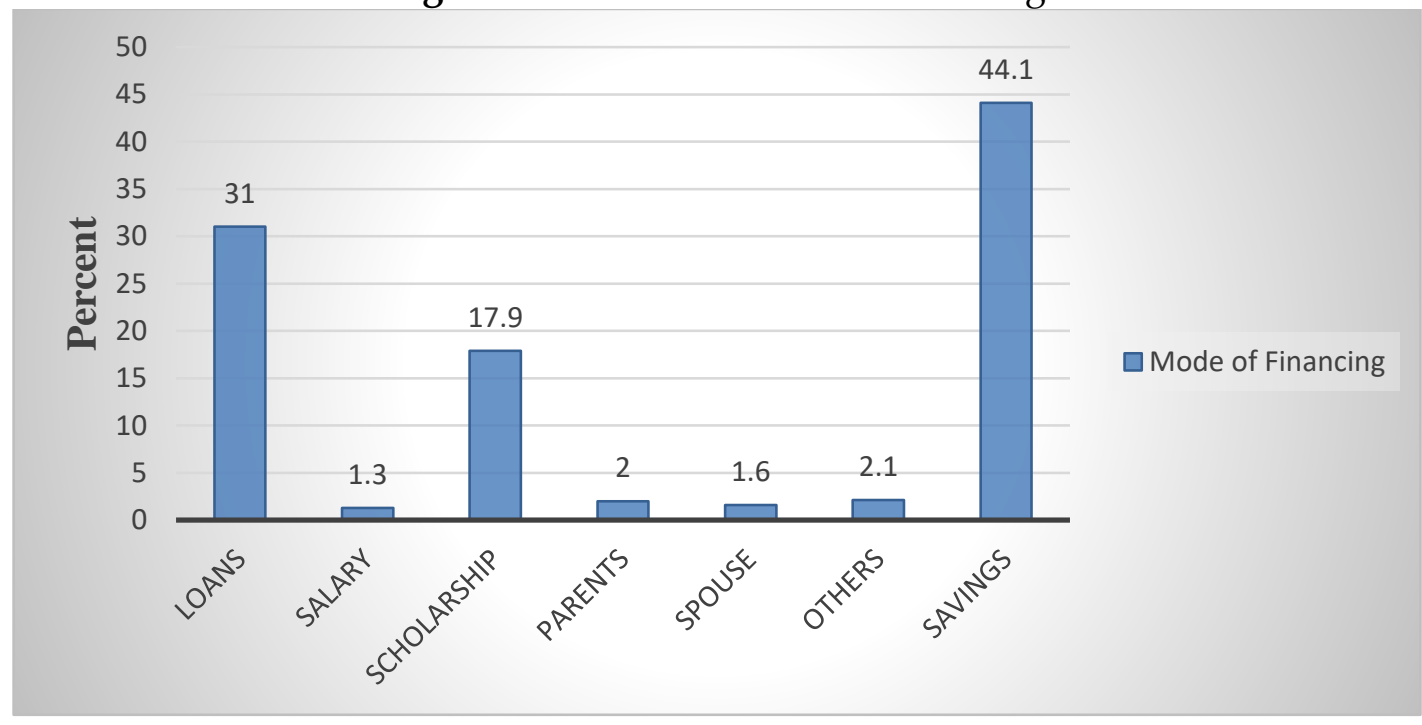


From Figure 2, 44.1\% of the participants financed their studies through savings, 31\% took loans to finance their studies, while $17.9 \%$ had scholarships. Several studies have shown a relationship between finances and non-completion. Garwe and Maganga's (2015), study in Zimbabwe revealed that graduation rates decreased from $86 \%$ in the 2009 cohort to $76 \%$ in the 2010 cohort and 75\% in the 2011 cohort the decline in graduation rates was attributed to inadequate funds channeled to higher education. While Rauf's (2016), study in Sri Lanka reported that $15 \%$ of the respondents strongly agreed that financial resources were a barrier to their thesis completion. Jiranek (2010) found out that students with scholarships had high completion rates. Rong'uno (2016) documented that students with scholarships were most likely to finish their dissertation writing within a reasonable period compared to their counterparts. Rung'uno also indicated that self-funding postgraduate students were less likely to finish their learning and graduate in a timely in contrast to those who received funding irrespective of the type of funding.

\section{f. Perception of Students on Lack of Finances as a Cause of Non-Completion}

To further understand the impact of finances on non-completion, the participants were required to indicate their perception of lack of finances as the cause for the noncompletion of studies.

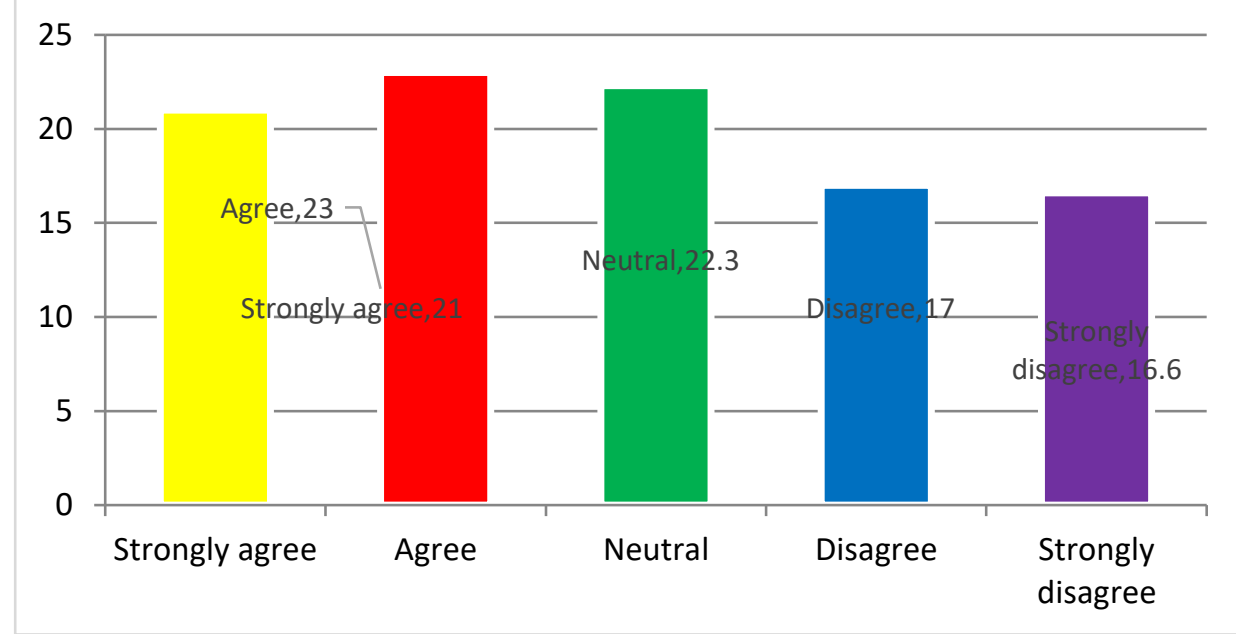

Figure 1: Lack of Finances as Cause of Non-Completion

As shown in Figure 3, 23\% of the students agreed that lack of adequate finances caused non-completion, $22 \%$ indicated neutral, while $21 \%$ strongly agreed that lack of finances caused non-completion of academic studies. Even though financial status was not a main variable of the study, it was important to understand how it influenced the study's dependent variable which was the intervening variable. It was important for this study to feature this factor because several researchers in the past had established that finances played a major role in non-completion among postgraduate students (Garwe, \& Maganga 2015; Rauf, 2016). The above findings indicated that finances had been a primary contributor to non-completion. 
g. Prevalence of non-completion among postgraduate students in selected public universities in Kenya

The study objective sought to establish the prevalence of non-completion among postgraduate students in selected public universities in Kenya. To achieve this, participants were required to stipulate their level of academic work and further required to indicate their year of enrolment and year of expected graduation. Table 5 presents findings of students' level of academic. This data was vital in this study because it gave the examiner the details of how long the students had progressed with their postgraduate studies and how far they were from graduating. This data additionally gave the investigator information on how many years the students had spent in their studies. With this information, the researcher could determine the rate of non-completion years. The data also indicated the stage of postgraduate study, where many students likely to waste more time than required.

Table 5: Level of Academic Work

\begin{tabular}{|l|c|c|}
\hline Level of Academic Work & Frequency & Percent \\
\hline Concept development & 31 & 13.5 \\
\hline Course work & 26 & 11.4 \\
\hline Data collection & 35 & 15.3 \\
\hline Graduated & 1 & 0.4 \\
\hline Proposal development & 83 & 36.2 \\
\hline Report writing & 53 & 23.1 \\
\hline Total & 229 & 100.0 \\
\hline
\end{tabular}

From Table 5, 36.2\% of participants were developing their proposal, $23.1 \%$ were writing their project report, $15.3 \%$ were collecting data, while $13.5 \%$ were developing their concept paper. According to the above data many of the students were at proposal development. Van de Schoot, Yerkes, Mouw and Sonneveld (2013), reported that proposal development and research took much time and delayed PhD students from graduating.

Table 6 shows the participant's year of enrolment to achieve this data the researcher calculated the prevalence of non-completion by subtracting the expected year of graduation from the current year of the research study (2020). The year of enrollment was crucial in the study because it told the researcher how long the students was in school. Without understanding the year of enrollment, it would have been difficult to know the rate of non-completion among the students. 
Table 6: Participants' year of Enrolment

\begin{tabular}{|l|c|c|}
\hline Enrolment Year & Frequency & Percent \\
\hline 2011 & 15 & 6.6 \\
\hline 2012 & 21 & 9.2 \\
\hline 2013 & 39 & 17.0 \\
\hline 2014 & 38 & 16.6 \\
\hline 2015 & 56 & 24.5 \\
\hline 2016 & 60 & 26.2 \\
\hline Total & 229 & 100.0 \\
\hline
\end{tabular}

As shown in Table 6, 26.2\% of students were enrolled in 2016, 24.5\% were enrolled in $2015,17 \%$ were enrolled in 2013 , while $16.6 \%$ of students were enrolled in 2014 . The data shows that some students did their course for more than six years, while others completed the same course in three years. This data was among the founding information for this research.

The findings of Table 7 presented a summary of the students' expected year of graduation that contributed to the findings on the prevalence of non-completion among University Students.

Table 7: Students Expected Graduation Date

\begin{tabular}{|l|c|c|}
\hline Expected Graduation Date & Frequency & Percent \\
\hline 2014 & 10 & 4.4 \\
\hline 2015 & 14 & 6.1 \\
\hline 2016 & 35 & 15.3 \\
\hline 2017 & 41 & 17.9 \\
\hline 2018 & 57 & 24.9 \\
\hline 2019 & 72 & 31.4 \\
\hline Total & 229 & 100.0 \\
\hline
\end{tabular}

From Table 7, 31.4\% of students indicated they were expected to graduate in $2019,24.9 \%$ indicated that were expected to graduate in 2018, while $17.9 \%$ were expected to graduate in 2017. Compared to table 6 data on the enrollment year, understanding the expected year of graduation was important in this study because it gave the examiner the information on how many years the students are supposed to finish their degrees. With the information, it was easier for the researcher to find out if students had spent more time than expected in their studies. Also, comparing it with the current year of this research, the scholar could estimate if students extended their time of study depending on where they were currently with their studies. This data was vital for the research as non-completion was a major question of the study.

Findings on the prevalence of non-completion were presented in Table 8. 
Sophia Mwende Mugendi, Eunice Njango Githae

PREVALENCE OF NON-COMPLETION AMONG POSTGRADUATE

STUDENTS IN SELECTED PUBLIC UNIVERSITIES IN KENYA

Table 8: Prevalence of Non-Completion

\begin{tabular}{|l|c|c|}
\hline Prevalence of Non-Completion & Frequency & Percent \\
\hline 1 year & 72 & 31.4 \\
\hline 2 years & 57 & 24.9 \\
\hline 3 years & 41 & 17.9 \\
\hline 4 years & 35 & 15.3 \\
\hline 5 years & 14 & 6.1 \\
\hline 6 years & 10 & 4.4 \\
\hline Total & 229 & 100.0 \\
\hline
\end{tabular}

As shown in Table 8, 31.4\% of the students had overstayed in school for one year, $24.9 \%$ had overstayed for 2 years, $17.9 \%$ for 3 years, while $4.4 \%$ had overstayed for 6 years. The prevalence of non-completion was further analyzed descriptively using means and standard deviation.

Table 9: Descriptive Statistics on Prevalence of Non-completion

\begin{tabular}{|l|l|c|c|c|c|}
\hline & N & Minimum & Maximum & Mean & Std. Deviation \\
\hline Non-completion & 229 & 1 & 6 & \multirow{2}{*}{2.53} & \multirow{2}{*}{1.443} \\
\hline Valid N (listwise) & 229 & & & \\
\hline
\end{tabular}

As shown in Table 9, the lowest non-completion score was 1 year, while the highest score was 6 years. The mean score was $2.53(\mathrm{SD}=1.443)$, signified that on average the students had a non-completion prevalence of 2 and a half years. The prevalence of non-completion was further analyzed by universities. The findings were presented in tables 10 and 11 respectively.

Table 10: Prevalence of Non-completion by University Enrollment

\begin{tabular}{|l|c|c|c|}
\hline University Enrolled & Years & Frequency & Percent \\
\hline \multirow{4}{*}{ Kenyatta University } & 1 year & 43 & 34.1 \\
\cline { 2 - 4 } & 2 years & 31 & 24.6 \\
\cline { 2 - 4 } & 3 years & 22 & 17.5 \\
\cline { 2 - 4 } & 4 years & 14 & 11.1 \\
\cline { 2 - 4 } & 5 years & 9 & 7.1 \\
\cline { 2 - 4 } & 6 years & 7 & 5.6 \\
\cline { 2 - 4 } & Total & 126 & 100.0 \\
\hline \multirow{5}{*}{ Moi University } & 1 year & 29 & 28.2 \\
\cline { 2 - 4 } & 2 years & 26 & 25.2 \\
\cline { 2 - 4 } & 3 years & 19 & 18.4 \\
\cline { 2 - 4 } & 4 years & 21 & 20.4 \\
\cline { 2 - 4 } & 5 years & 5 & 4.9 \\
\cline { 2 - 4 } & 6 years & 3 & 2.9 \\
\cline { 2 - 4 } & Total & 103 & 100.0 \\
\hline
\end{tabular}

As shown in Table 10, 34.1\% of students in Kenyatta University had a non-completion prevalence of 1 year, $24.6 \%$ had a non-completion prevalence of 2 years, while $17.5 \%$ had a non-completion prevalence of 3 years. On the other hand, $28.2 \%$ of students from Moi 
University had a non-completion rate of 1 year, $25.2 \%$ had a non-completion rate of 2 years, while $20.4 \%$ had a non-completion rate of 4 years.

Table 11 presented descriptive statistics of prevalence of non-completion by university enrolled and it established the mean score for the students in Kenyatta University was 2.49 ( $\mathrm{SD}=1.506)$, signifying that on average the students had a noncompletion prevalence of 2 and a half years. The mean score for the students in Moi University was $2.57(\mathrm{SD}=1.369)$, signifying that on average the students had a noncompletion prevalence of 2 and a half years.

Table 11: Descriptive Statistics of Prevalence of Non-completion by University Enrolled

\begin{tabular}{|c|c|c|c|c|c|c|}
\hline \multicolumn{2}{|l|}{ University Enrolled } & $\mathbf{N}$ & Minimum & Maximum & Mean & Std. Deviation \\
\hline \multirow{2}{*}{ Kenyatta University } & Non-completion & 126 & 1 & 6 & \multirow{2}{*}{2.49} & \multirow{2}{*}{1.506} \\
\hline & Valid N (listwise) & 126 & & & & \\
\hline \multirow{2}{*}{ Moi University } & Non-completion & 103 & 1 & 6 & \multirow{2}{*}{2.57} & \multirow{2}{*}{1.369} \\
\hline & Valid N (listwise) & 103 & & & & \\
\hline
\end{tabular}

As shown in Table 11, the lowest non-completion score for students in Kenyatta University and Moi University was 1 year, while the highest score was 6 years. The four tables above 8, 9 (for all participants); 10, and 11 (per each university) represented data on the prevalence of non-completion among students in the selected universities. Prevalence of non-completion among university students was studied in the past and several researchers established the prevalence of non-completion among postgraduate students (Barefoot 2004; Cutler \& Pulko 2002; Danaher et al. 2008; Herman, 2011; McKennzie,2005; Mukami, 2016).

\section{Conclusion}

The study concluded that Students delayed completion in their postgraduate studies at an average rate of 2.5 years indicating a wastage of time and delays in career achievement. Most students felt that financial constraint was the primary cause of their non-completion.

\section{Recommendations}

Students who wished to further their studies should first establish a financial channel or safe for the education journey before they registered for their studies. This would ensure that they would avoid dropping out of school due to a lack of school fees. The study further recommended that students should plan for their study schedules and ensure that the study period was not interrupted by roles that could be put on hold. For instance, females should decide to further their studies when they were sure they do not have a parenting role that could tie them down for a long period. The study also recommended that the students should choose a study model that would favor their schedules to ensure 
that they did not go through a lot of stress trying to accomplish several tasks simultaneously.

\title{
Conflict of Interest Statement
}

The authors declare no conflicts of interests.

\begin{abstract}
About the Authors
Sophia Mwende Mugendi is a probation officer at Government of Kenya. She is also a practicing counsellor offering virtual and in person counselling sessions. She holds a Master of Arts Degree in Counselling Psychology from Kenyatta University.

Dr. Eunice Njanjo Githae is the chairperson of Psychology Department, Kenyatta University. Experienced in Counselling Psychology, Substance Abuse and Addiction. Has long university teaching experience and student supervision.
\end{abstract}

\section{References}

\section{a. Journal articles}

Anderson, Joel R, Guan, Yao and Koc, Yasin (2016). The academic adjustment scale: measuring the adjustment of permanent resident or sojourner students. International Journal of Intercultural Relations, 54. pp. 68-76. ISSN 0147-1767

Barefoot, B. O. (2004). Higher education's revolving door: Confronting the problem of student drop-out in US colleges and universities. Open Learning: The Journal of Open, Distance and e-Learning, 19(1), 9-18.

Cutler, G. L. \& Pulko, S. H. (2002). Investigating UK undergraduate electrical and electronic engineering attrition. International Journal Electrical Engineering Education. 39(3):181-191.

Danaher, P.A., Bowser, D. \& Somasundaram, J. (2008). The student departure puzzle Do some faculties and programs have answers? Higher Education Journal http://dx.doi.org/10.1080/07294360802183820

Garwe, E. C., \& Maganga, E. (2015). The effect of student financial constraints on university non-completion rates. International Journal of Education, 7(2), 322-336.

Golde, C. M. (2005). The role of department and discipline in doctoral student attrition: Lessons from four departments. The Journal of Higher Education, 76(6): 669-700.

Herman, C. (2011). Obstacles to success-doctoral student attrition in South Africa, Perspective in Education, 29(3).40-52.

Ishitani, T. T. (2006). Studying attrition and degree completion behavior among first generation college students in the United States. The Journal of Higher Education, 77(5), 861-885.

Jiranek, V. (2010). Potential predictors of timely completion among dissertation research students at an Australian faculty of sciences. International Journal of Doctoral Studies, 5(1), 1-13. 
Kyalo, P. M. \& Chumba. J. (2011). Selected factors influencing social and academic adjustment of undergraduate students of Egerton University Njoro Campus, International Journal of Business and Social Science, 2(18).

McKenzie, D. F. (2005). Reducing attrition rates for Maori students. Journal of developmental education, 28 (3):12-18.

Mouton, Johann (2011) Doctoral production in South Africa: Statistics, challenges and response. Perspective in Education Journal. 29(3):13-29

Mukami, M. N., \& Wang'eri, T. (2016). Examination repeats, semester deferment and dropping out as contributor of attrition rates in private universities in Nairobi County, Kenya. International Journal of Education and Research. 4(3), 225-237

Mwebi, B., \& Simatwa, E. M. (2013). Expansion of private Universities in Kenya and its implication on quality and completion rate: An analytical study. Educational Research, 4, 352-366.

Rauf, F. A. (2016). Challenges of thesis work: towards minimizing the non-completion rate in the postgraduate degree program. concern, $8(7)$.

Rhea, W., Kevin, E. \&, Derek, K. L. (2013). Student attrition in the Ontario midwifery education Programme, Midwifery, Volume 29, issue 4 https://doi.org/10.1016/j.midw.2012.04.015.

Rosliza, G., Inayah, A. A., Emiza, T., Merani, C. A., \& Yusliena, Y. (2017). Towards an Islamic spirituality model in increasing academic performance of accounting students. Journal of Fundamental and Applied Sciences, 9(5S), 921-931.

Taghavinia, M. \& Motavassel, M. (2015). The Relationship between religiosity and academic achievement in students of Tehran University of medical sciences. Iranian Journal of Medical Education, 15, 19-26.

Ugolini M. (2000). University dropout, a problem and an opportunity. Sinergie Rapporti di Ricerca. 9:417-436.

Van de Schoot, R., Yerkes, M. A., Mouw, J. M., \& Sonneveld, H. (2013). What took them so long? Explaining PhD delays among doctoral candidates. PloS one, 8(7), e68839.

Yusuf, Felicia O. and Aina, L.O. (2018) Demographic factors as correlates of doctoral degree completion in Nigeria library schools. Annals of Library and Information Studies, 65. pp. 177-186

Zubairu, U. M. \& Sakariyau, O. B. (2016). The Relationship between Religiosity and Academic Performance amongst Accounting Students. International Journal of Evaluation and Research in Education, 5(2), 165-173.

\section{b. Theses}

Elms, R. T. (2007). The Role of Religiosity in Academic Success: A Qualitative Study (Doctoral dissertation, Washington State University).

Rong'uno, K. S. (2016). The Institutional and student related factors and doctoral studies completion rates in Education at selected public universities in Kenya. International Journal of humanities and social sciences. (Doctoral dissertation, University of Nairobi) 
Lindsay Declou (2013). Linking to understand graduate student in Canada. (Doctoral dissertation, McMaster University).

\section{c. Books}

Barasa, P. L., \& Omulando, C. (2018). Research and Ph.D. capacities in Sub-Saharan Africa; Kenya report. African Network for Internationalisation of Education (ANIE). Retrieved from https://www2.daad.de/medien/derdaad/analysenstudien/research and phd cap acities in sub-saharan africa - kenya report.pdf

Bowen, W. G., Chingos, M. M., \& McPherson, M. S. (2009). Crossing the finish line: Completing College at America's public universities. Princeton, NJ: Princeton University Press.

Gates Foundation. (2009). With their whole lives ahead of them [homepage on the Internet]. $\quad$ [Cited $2019 \quad$ December 17]. http://www.Publicagenda.org/TheirWholeLivesAheadofThem.

GradSchoolHub, (2020). What is the Average Age of a Graduate Student? Retrieved from: https://www.gradschoolhub.com/faqs/what-is-the-average-age-of-a-graduatestudent.

Grayson, J. P. (1998). Racial origin and student retention in a Canadian University, http://dx.doi.org/10.1023/A:1003229631240

Lambert, M., Zeman, K., Allen, M., \& Bussière, P. (2004). Who pursues postsecondary education, who leaves and why: Results from the Youth in Transition Survey. Ottawa, ON: Statistics Canada \& Human Resources and Skills Development Canada.

Mulvey, P. J., \& Nicholson, S. (2014). Trends in Exiting Physics Master's.

Nettles, M., \& Millet, C. (2006). Three magic letters: Getting to PhD. Johns Hoping University Press-ISBN:0-8018-8232X.

Shaienks, D., \& Gluszynski, T. (2007). Participation in postsecondary education: Graduates, continuers and drop outs. Results from YITS cycle 4. Ottawa, ON: Statistics Canada \& Human Resources and Social Development Canada. 
Sophia Mwende Mugendi, Eunice Njango Githae

PREVALENCE OF NON-COMPLETION AMONG POSTGRADUATE

STUDENTS IN SELECTED PUBLIC UNIVERSITIES IN KENYA

Creative Commons licensing terms

Author(s) will retain the copyright of their published articles agreeing that a Creative Commons Attribution 4.0 International License (CC BY 4.0) terms will be applied to their work. Under the terms of this license, no permission is required from the author(s) or publisher for members of the community to copy, distribute, transmit or adapt the article content, providing a proper, prominent and unambiguous attribution to the authors in a manner that makes clear that the materials are being reused under permission of a Creative Commons License. Views, opinions and conclusions expressed in this research article are views, opinions and conclusions of the author(s). Open Access Publishing Group and European Journal of Education Studies shall not be responsible or answerable for any loss, damage or liability caused in relation to/arising out of conflicts of interest, copyright violations and inappropriate or inaccurate use of any kind content related or integrated into the research work. All the published works are meeting the Open Access Publishing requirements and can be freely accessed, shared, modified, distributed and used in educational, commercial and non-commercial purposes under a Creative Commons Attribution 4.0 International License (CC BY 4.0). 